\title{
Recombinant expression, characterization and application of a dihydrolipoamide dehydrogenase with diaphorase activity from Bacillus sphaericus
}

\author{
Anvarsadat Kianmehr ${ }^{1,2} \cdot$ Rahman Mahdizadeh $^{3} \cdot$ Morteza Oladnabi $^{4}$. \\ Javad Ansari ${ }^{5}$
}

Received: 2 November 2016/ Accepted: 2 February 2017/Published online: 8 June 2017

(c) Springer-Verlag Berlin Heidelberg 2017

\begin{abstract}
Diaphorases are flavin-containing enzymes with potential applications in biotransfomation reactions, biosensor design and in vitro diagnostic tests. In this communication, we describe recombinant expression, characterization and application of a lipoamide dehydrogenase (DLD) with diaphorase activity from a strain of Bacillus sphaericus. The DLD gene consisting of $1413 \mathrm{bp}$ encoding a protein of 470 amino acids was expressed in Escherichia coli BL21 (DE3) and the recombinant enzyme was characterized. B. sphaericus DLD catalyzed the reduction of $\mathrm{NAD}^{+}$by dihydrolipoamide and exhibited NADH-dependent diaphorase activity. The molecular weight of purified enzyme was about $50 \mathrm{kDa}$, and determined to be a monomeric protein. Diaphorase was active and stable from $\mathrm{pH} 7.0$ to 9.0 with an optimal activity at $\mathrm{pH}$ 8.5. It showed its maximal activity at temperature of $30{ }^{\circ} \mathrm{C}$ and was almost stable at temperatures between 25 and $30{ }^{\circ} \mathrm{C}$. Different metal ions and inhibitors showed no influence on the activity of target enzyme. The $K_{\mathrm{m}}$ and $V_{\max }$ values for NADH were estimated to be $0.33 \mathrm{mM}$ and
\end{abstract}

Rahman Mahdizadeh

R.Mahdizadeh@iauba.ac.ir

1 Biochemistry and Metabolic Disorders Research Center, Golestan University of Medical Sciences, Gorgan, Iran

2 Department of Medical Biotechnology, School of Advanced Technologies in Medicine, Golestan University of Medical Sciences, Gorgan, Iran

3 Bandar Abbas Branch, Department of Nursing, Islamic Azad University, Bandar Abbas, Iran

4 Gorgan Congenital Malformations Research Center, Golestan University of Medical Sciences, Gorgan, Iran

5 Cellular and Molecular Research Center, Qazvin University of Medical Sciences, Qazvin, Iran
$200.0 \mathrm{U} / \mathrm{ml}$, respectively. Moreover, recombinant $B$. sphaericus diaphorase exhibited considerable potential to be used as a component of diagnostic tests for the quantification of metabolites. In conclusion, considering the properties of diaphorase from B. sphaericus PAD-91, it can have potential application as a diagnostic enzyme.

Keywords Bacillus sphaericus . Characterization · Lipoamide dehydrogenase (DLD) - Diaphorase

\section{Introduction}

Dihydrolipohyl dehydrogenase (DLD; EC: 1.8.1.4), also known as lipoamide dehydrogenase, is a FAD-dependent enzyme that catalyses the reversible oxidation of dihydrolipoamide to lipoamide (Vaubel et al. 2011). DLD is a flavoenzyme oxidoreductase that contains a reactive disulfide bridge and a FAD cofactor per subunit. It has been extensively isolated from a variety of organisms belonging to prokaryotes, eukaryotes and archaeobacteria (Serrano 1992; Benen et al. 1989). Some of DLD enzymes are also termed diaphorase for their $\mathrm{NAD}(\mathrm{P}) \mathrm{H}$ dehydrogenase activities (Madiagan and Mayhew 1993). Diaphorase activity may have an antioxidant role through its ability to scavenge nitric oxide and to reduce ubiquinone to ubiquinol (Xia et al. 2001). The first such enzyme has been purified from pig heart muscle (Rlyachko et al. 2006). Other enzymes have been identified from various sources such as Clostridium kluyveri, Bacillus stearothermophilus, Thermus aquaticus and Thermus thermophlius (Cakraborty et al. 2008; Antiochia et al. 1997). Diaphorases are a group of flavin-bound enzymes that catalyse the pyridine nucleotide-dependent reduction of electron-accepting molecules such as $\mathrm{O}_{2}$, nitric oxide and ubiquinone 
(Tedeschi et al. 1995; Adams and Jia 2006; Yan et al. 2013). These enzymes have potential application to be used as a component of assay systems for the determination of different substances such as leucine, phenylalanine and ethanol. They have been used in biotransfomation reactions (Bhushan et al. 2002), biosensor design (Antiochia et al. 1997) and in vitro diagnostic tests such as phenylketonuria (PKU) (Dilipkumar et al. 2013; Shahbazmohammadi and Omidinia 2011), maple syrup urine diseases (MSUD) and galactosemia as well (Kianmehr et al. 2016). Due to industrial applications of diaphorases, these enzymes have attracted researcher's attentions for screening of novel sources and cost-benefit production. In this literature, we report a strain of $B$. sphaericus which produced a DLD with NADH-dependent diaphorase activity and examined its potential application as a diagnostic enzyme.

\section{Materials and methods}

\section{Chemicals}

$\mathrm{NAD}^{+}$was obtained from Sigma (St. Louis, MO, USA) and $\mathrm{NADH}$ was from Roche (Germany). Galactose and galactose-1-phosphate were obtained from Merck (Darmstadt, Germany). INT (2-( $p$-iodophenyl)-3-( $p$-nitrophenyl)5 -phenyltetrazolium chloride) was purchased from SigmaAldrich Corp (St. Louis, MO, USA). Escherichia coli BL21 (DE3) and pET-28b (+) were purchased from Novagen (Philadelphia, PA).

\section{Screening of strains producing enzyme}

One gram of each soil sample was suspended in selective liquid medium that contained (per liter) $0.5 \%$ lipoamide, $1 \mathrm{~g} \mathrm{NaCl}, 2 \mathrm{~g} \mathrm{~K}_{2} \mathrm{HPO}_{4}, 0.5 \mathrm{~g} \mathrm{MgSO}_{4} \cdot 7 \mathrm{H}_{2} \mathrm{O}, 5 \mathrm{~g}$ yeast extract, $5 \mathrm{~g}$ polypeptone in 11 of tap water, $\mathrm{pH} 7.0$ and then incubated with shaking at $37^{\circ} \mathrm{C}$ at $180 \mathrm{rpm}$ for $24 \mathrm{~h}$ (Shahbazmohammadi et al. 2007). From each culture, $0.05 \mathrm{ml}$ was taken and placed on agar plates and incubated at $37{ }^{\circ} \mathrm{C}$ for $24 \mathrm{~h}$. The strains that grew under such conditions were selected for enzyme production analysis. Production of enzyme was done in the above mentioned medium at $37{ }^{\circ} \mathrm{C}$ at $180 \mathrm{rpm}$ for $24 \mathrm{~h}$. After the completion of growth, the fermentation broth was centrifuged at $8000 \mathrm{rpm}$ for $15 \mathrm{~min}$ at $4{ }^{\circ} \mathrm{C}$. The harvested cells were washed twice with $0.9 \% \mathrm{NaCl}$ solution, suspended in buffer $\mathrm{A}\left(50 \mathrm{mM} \mathrm{NaH} \mathrm{PO}_{4}, 300 \mathrm{mM} \mathrm{NaCl}, \mathrm{pH}\right.$ 7.4) and disrupted by ultrasonic oscillator for $10 \mathrm{~min}$. Cells and insoluble materials were removed by centrifugation at $10,000 \mathrm{rpm}$ for $20 \mathrm{~min}$ at $4{ }^{\circ} \mathrm{C}$. The supernatant solution was used as crude extract for DLD activity assay (Mashayekhi Mazar et al. 2012). DLD activity was determined by the oxidation of dihydrolipoamide in the presence of $\mathrm{NAD}^{+}$(Argyrou et al. 2003). The reaction mixture $(1 \mathrm{ml})$ contained $100 \mathrm{mM}$ potassium phosphate buffer ( $\mathrm{pH}$ 7.8), $1.0 \mathrm{mM}$ EDTA, $0.4 \mathrm{mM}$ dihydrolipoamide and $0.3 \mathrm{mM} \mathrm{NAD}^{+}$. A solution containing all assay components except dihydrolipoamide was used as the blank. The assay was monitored by the increase in absorbance at $340 \mathrm{~nm}$ for $3 \mathrm{~min}$. The isolates that showed DLD activity were selected for diaphorase assay. Diaphorase activity was measured using thiazolyl blue tetrazolium bromide (MTT) assay as a terminal electron acceptor. The standard reaction mixture was composed of $0.1 \mathrm{M}$ potassium phosphate buffer ( $\mathrm{pH} 7.6$ ), $0.3 \mathrm{mM}$ NADH, $0.4 \mathrm{mM}$ MTT and the enzyme in a total volume of $0.7 \mathrm{ml}$. The increase in absorbance at $560 \mathrm{~nm}$ for 1 min was estimated and corrected for blank values lacking enzyme. One unit (U) of diaphorase activity was defined as the quantity of enzyme, which transfers electrons from $1 \mu \mathrm{mol}$ of NADH to MTT per minute at $25^{\circ} \mathrm{C}$. All assay experiments were done in triplicate and the average results were used for data analysis (Boething and Weaver 1979).

\section{Isolate identification}

Identification of bacterium was done by $16 \mathrm{~S}$ rRNA sequencing. Polymerase chain reaction (PCR) of $16 \mathrm{~S}$ rRNA gene was performed with universal primer pair $27 \mathrm{~F}$ (AGAGTTTGATCCTGGCTCAG) and 1492R (AAGGAGGTGATCCAGCCGCA) (Ki et al. 2009). The PCR program was as follows: $95^{\circ} \mathrm{C}$ for $5 \mathrm{~min}, 30$ cycles of $95{ }^{\circ} \mathrm{C}$ for $1 \mathrm{~min}, 45^{\circ} \mathrm{C}$ for $1 \mathrm{~min}$, and $72^{\circ} \mathrm{C}$ for $2 \mathrm{~min}$ and final extension at $72{ }^{\circ} \mathrm{C}$ for $10 \mathrm{~min}$. DNA sequencing was performed by the commercial services of MacroGen Co. Ltd. (Seoul, Korea). The 16S rRNA genes of the isolate and Bacillus type strains were aligned using the Molecular Evolution Genetic Analysis (MEGA) program, version 5.0 (Tamura et al. 2011). Phylogenic tree was constructed using the neighbor-joining algorithm using the MEGA version 5.0.

\section{Expression and purification}

To amplify the $D L D$ gene, forward and reverse primers were designed based on the consensus sequences among the Bacillus species using DNASIS MAX software (DNASIS version 3.0, Hitachi Software Engineering Co., Ltd., Tokyo, Japan). The primers used were DLDFw (5'CCCGGATCCATGGTAGTAGGAGA-3') and DLDRev $\left(5^{\prime}\right.$ - CCCGTCGACTTATTTTACAATGTG-3'), which contained the restriction sites for BamHI and SalI, respectively (underlined). PCR conditions were as follows: initial denaturation at $95{ }^{\circ} \mathrm{C}$ for $5 \mathrm{~min}, 30$ cycles at $95{ }^{\circ} \mathrm{C}$ for $1 \mathrm{~min}, 60^{\circ} \mathrm{C}$ for $1 \mathrm{~min}, 72^{\circ} \mathrm{C}$ for $2 \mathrm{~min}$ and a final 


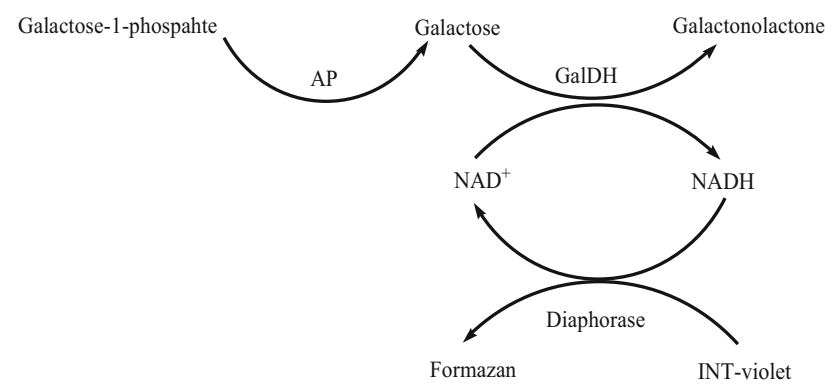

Fig. 1 Schematic representation of diaphorase role in galactose determination test

extension step at $72{ }^{\circ} \mathrm{C}$ for $7 \mathrm{~min}$. The construct bearing the desired gene (pET28aDLD) was transformed into E. coli strain BL-21 (DE3) competent cells for expression. E. coli strain BL21 (DE3) cells bearing pET28aDLD were cultivated overnight in $100 \mathrm{ml}$ of Luria-Bertani (LB) medium containing $40 \mu \mathrm{g} / \mathrm{ml}$ of kanamycin at $37{ }^{\circ} \mathrm{C}$ and $180 \mathrm{rpm} .100 \mathrm{ml}$ of precultured medium was transferred into 11 of LB medium in culture flasks and incubated at $37^{\circ} \mathrm{C}$ and $250 \mathrm{rpm}$. When cell density reached an $\mathrm{OD}_{600}$ of $0.6-0.8$, DLD enzyme was expressed by the addition of $1 \mathrm{mM}$ sterile isopropyl- $\beta$-D-thiogalactopyranoside (IPTG). After $5 \mathrm{~h}$ of induction at $37{ }^{\circ} \mathrm{C}$, cells were harvested, dissolved in lysis buffer and disrupted by sonication. To purify the recombinant protein, supernatant of cell lysis was applied to a Ni-NTA affinity column (Qiagen, Germany) according to the manufacture's instruction. The column was washed with 3 column volumes of the $50 \mathrm{mM}$ Tris-HCl buffer ( $\mathrm{pH}$ 7.0) containing $50 \mathrm{mM}$ imidazole, and then recombinant enzyme was eluted with an elution buffer $(50 \mathrm{mM}$ Tris- $\mathrm{HCl}, 50 \mathrm{mM} \mathrm{NaCl}, 10 \mathrm{mM}$ EDTA, $300 \mathrm{mM}$ imidazole, $\mathrm{pH}$ 7.0). Purity of enzyme sample was studied by sodium dodecyl sulfate polyacrylamide gel electrophoresis (SDS-PAGE). SDS-PAGE was performed using discontinuous gels $(10 \times 10 \mathrm{~cm})$ with a $12 \%$ separating gel and a 6\% stacking gel (Sambrook et al. 1994). Protein bands were visualized by staining with $0.25 \%$ Coomassie brilliant Blue R-250 in the mixture of $50 \%$ methanol and $10 \%$ acetate.

\section{Biochemical characterization}

\section{Determination of molecular mass}

The molecular mass of purified enzyme was determined by gel filtration on a Sephadex G-200 column gel filtration $(1.6 \times 60 \mathrm{~cm})$, which had been equilibrated with buffer A. The column was equipped with a high-performance liquid chromatography (HPLC) system. The flow rate was maintained at $1 \mathrm{ml} / \mathrm{min}$. Fractions of $2 \mathrm{ml}$ each were collected and absorbance at $280 \mathrm{~nm}$ was recorded.

\section{Effect of $\mathrm{pH}$ on the activity and stability}

The effect of $\mathrm{pH}$ was examined by measuring the activity in the following buffers: $0.1 \mathrm{M}$ sodium acetate $(\mathrm{pH}$ 3.0-5.0), 0.1 M potassium phosphate $(\mathrm{pH} 6.0-7.5) 0.1 \mathrm{M}$ Tris- $-\mathrm{HCl} \quad(\mathrm{pH} \quad 8.0-9.0), \quad 0.1 \mathrm{M}$ glycine- $\mathrm{NaOH} \quad(\mathrm{pH}$ 9.0-11.0) and $0.1 \mathrm{M}$ sodium carbonate ( $\mathrm{pH} 11.5-12.0$ ). The $\mathrm{pH}$ stability was studied by incubating the enzyme in the above mentioned buffers at a ratio of $1: 1$ at $4{ }^{\circ} \mathrm{C}$ for $24 \mathrm{~h}$. Aliquots were withdrawn at time intervals of $4 \mathrm{~h}$ and the residual activity was determined. All experiments were done in triplicate and repeated at least twice.

\section{Effect of temperature on the activity and stability}

The effect of temperature on the enzymatic activity was analyzed by performing the enzyme assay for $20 \mathrm{~min}$ at
Fig. 2 Phylogenetic tree of the 16S rDNA sequences of strain PAD-91 associated with the other members of Bacillus species. The scale bar indicates 0.005 nucleotide substitution per position

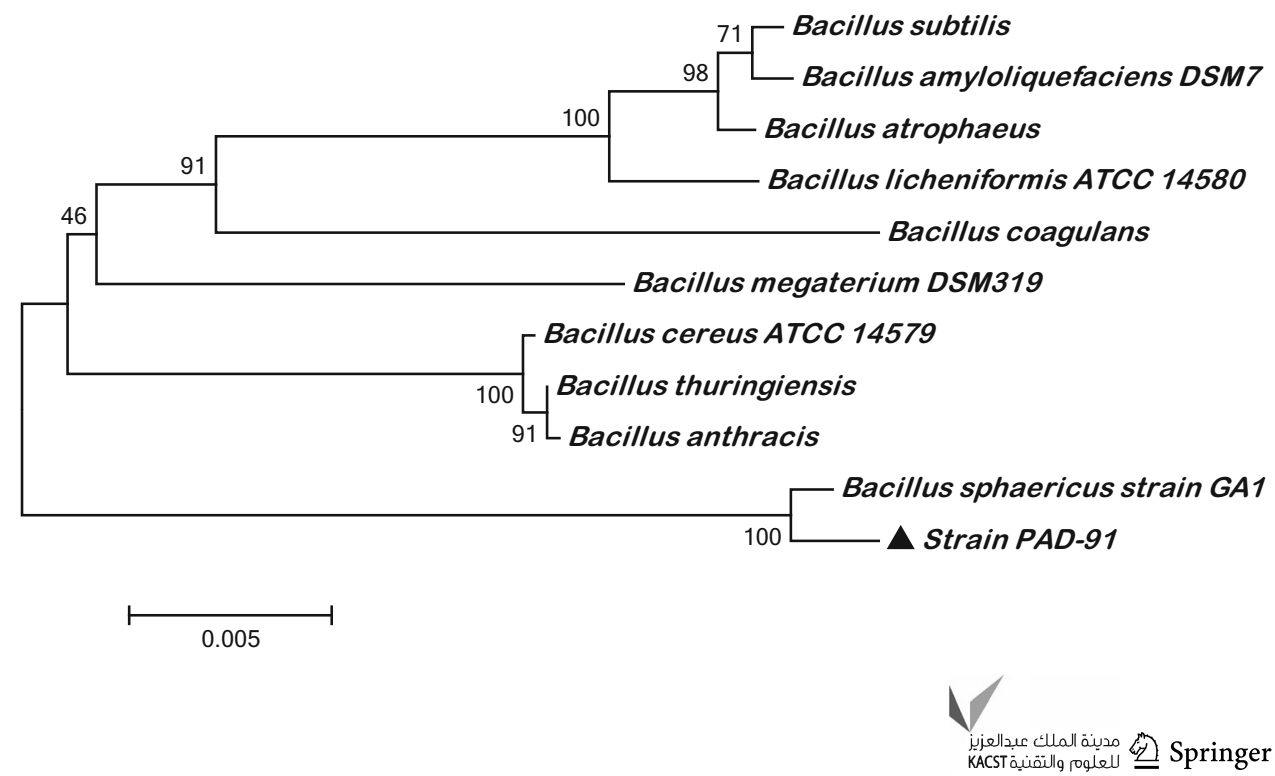




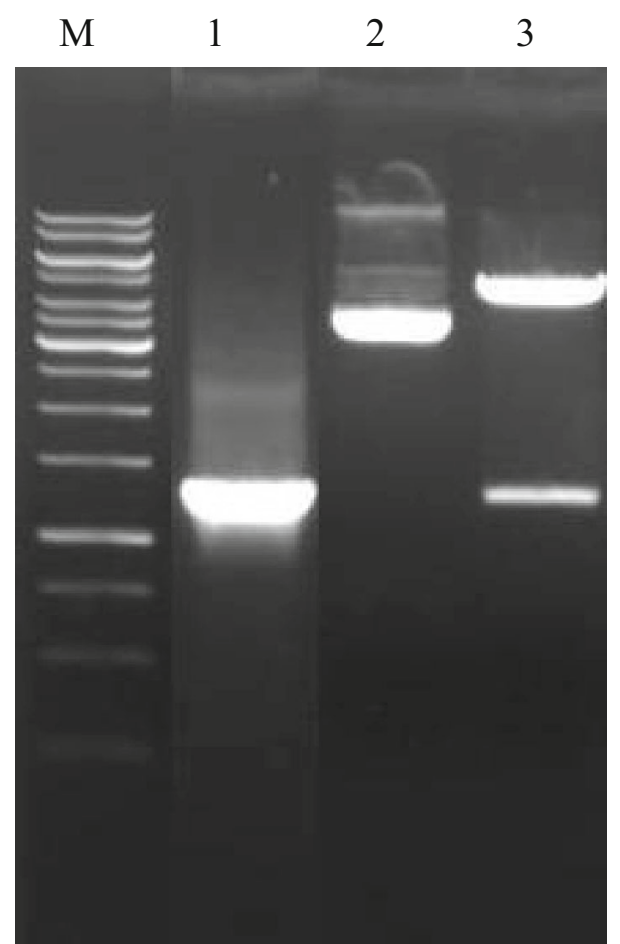

Fig. 3 PCR amplification of DLD gene and restriction analysis of pET28aDLD recombinant plasmid. Lane $M$ DNA molecular weight marker, lane 1 PCR product, lane 2 undigested pET28aDLD, lane 3 digested pET28aDLD with BamHI and SalI

different temperatures ranging from 30 to $70{ }^{\circ} \mathrm{C}$. The thermal stability was examined by incubating the enzyme at different temperatures ranging from 30 to $50{ }^{\circ} \mathrm{C}$ for $60 \mathrm{~min}$ and then cooling on ice-cold water. Residual activity was measured at every 10 -min interval under standard assay conditions. The non-heated enzyme was used as control.

\section{Effect of metal ions and inhibitors}

The effect of various metal ions at concentration of $5 \mathrm{mM}$ was studied by incubating the enzyme at $4{ }^{\circ} \mathrm{C}$ for $20 \mathrm{~min}$. The influence of enzyme inhibitors such as ethylene-diaminetetraacetic acd (EDTA) and phenylmethylsulfonyl fluoride (PMSF) on diaphorase activity was examined in a final concentration of $5 \mathrm{mM}$. Enzyme was pre-incubated with inhibitors at $37{ }^{\circ} \mathrm{C}$ for $30 \mathrm{~min}$ in $0.1 \mathrm{M}$ potassium phosphate (pH 7.6) and afterwards the residual activity was determined. The activity of the enzyme (without any additives) was taken as $100 \%$.

\section{Kinetic parameters}

The kinetic constants $\left(K_{\mathrm{m}}\right.$ and $\left.V_{\max }\right)$ were determined using GraphPad Prism version 7.00, (GraphPad Software, La Jolla California USA) with varying concentrations of
$\mathrm{NADH}$ as a substrate. For the determination of $K_{\mathrm{cat}}$ and $K_{\text {cat }} / K_{\mathrm{m}}$, the value of $V_{\max }$ was expressed in terms of $\mathrm{U} / \mathrm{ml}$.

\section{Evaluation of enzyme application}

To illustrate the effectiveness of target diaphorase as a diagnostic reagent, its application in a diagnostic assay, e.g., galactose quantification test was investigated. In this assay, galactose-1-phosphate is dephosphorylated to galactose by alkaline phosphates (AP), which activates a coupled redox cycle involving a galactose dehydrogenase $(\mathrm{GalDH})$ and diaphorase for the production of formazan product (Shahbazmohammadi et al. 2015) (Fig. 1). In the assay procedure, 5-mm (diameter) dried blood spot (DBS) from calibrator specimens were punched into a 96-well microlplate and left for $15 \mathrm{~min}$ at $95{ }^{\circ} \mathrm{C}$ in a bain-marie. Afterwards, $150 \mu \mathrm{l}$ of $0.1 \mathrm{M}$ phosphate buffer saline (PBS) ( $\mathrm{pH}$ 7.4) was added to each well and the plate was shaken for $60 \mathrm{~min}$ at $25^{\circ} \mathrm{C}$. The extracts were transferred to a microplate and the mixture of enzymes, coenzyme and INT reagent, was then added. To evaluate the role of $B$. sphaericus enzyme in improving of test performance, it was used in the second step in concentration of $4 \mathrm{U} / \mathrm{ml}$. After 30 min of shaking, the absorbance was read bichromatically at $490 / 630 \mathrm{~nm}$. The absorbance of a control sample (without diaphorase) was also read.

\section{Results and discussion}

\section{Phylogenetic analysis of isolate PAD-91}

To identify the enzyme producing microorganism, bacterial isolates were analyzed for DLD activity and NADH dehydrogenase ability. From these bacteria, only strain PAD-91 was found to have diaphorase activity. Strain identification was conducted by comparative sequence analysis of the 16S rDNA of isolate and other bacteria in the Genbank database. The 16S rRNA nucleotide was analyzed with the BLAST program and showed 97\% homology with $B$. sphaericus. According to the created phylogenetic tree (Fig. 2), it was inferred that the PAD-91 strain was closely related to $B$. sphaericus.

\section{Recombinant expression}

The DNA fragment containing $D L D$ gene was obtained by PCR with primers designed on the basis of conserved sequences from other Bacillus strains (Fig. 3). The 1413-bp open reading frame (ORF) had a coding capacity of 470 amino acids (Fig. 4). The DNA sequence showed 90.37 and $88.24 \%$ similarity to the gene encoding from $B$. anthracis and B. subtitlis, respectively. Also, the deduced 
a

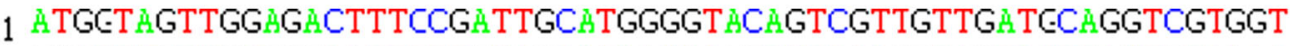

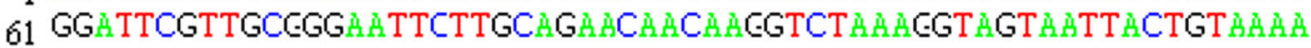

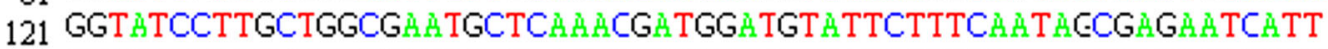

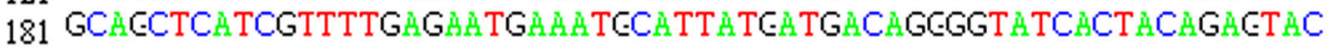
241 GTHATAGTTGACTTTACÄÄGTTCT

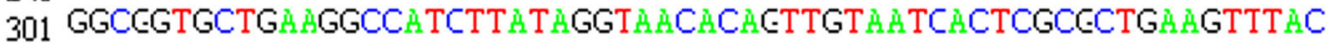

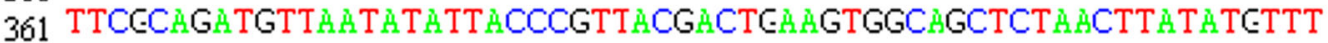

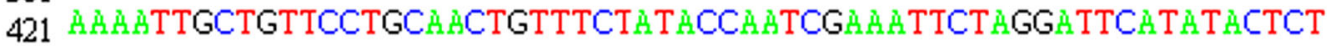

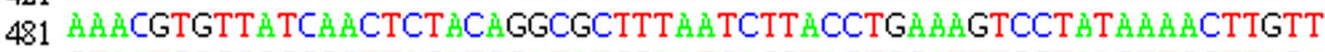

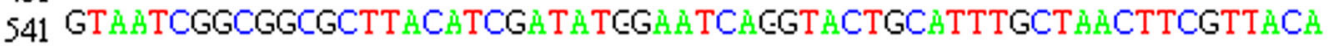
601 G쑉T

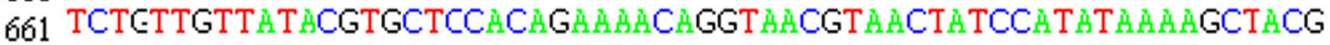
721 GCT

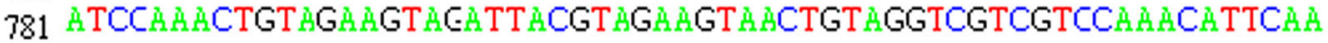
841 Gд дُ

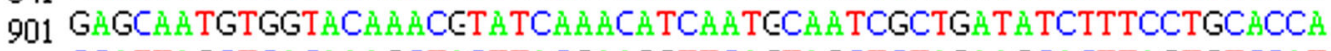

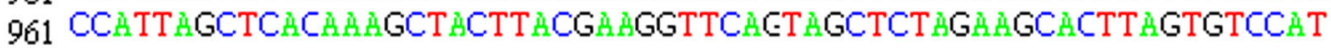

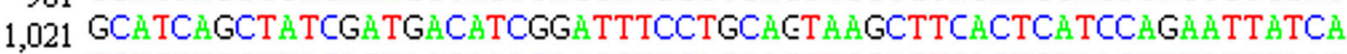

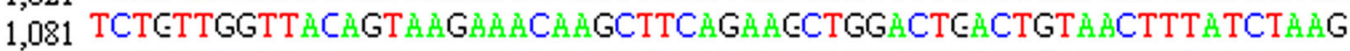
1,141 TTCCCATTCGCTGCTÄACGTAGTGCATTÀTCATTA TACAGCACTTACGGTTTCTTÄGG

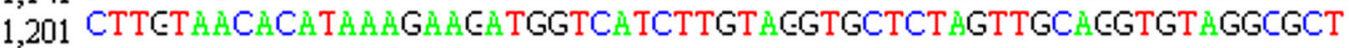

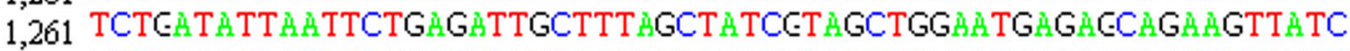

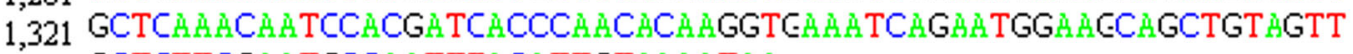

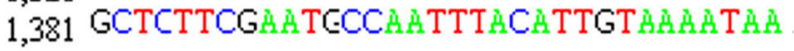

60

120

180

240

300

360

420

480

540

600

660

720

780

840

900

960

1,020

1,080

1,140

1,200

1,260

1,320

1,380

1,413

b

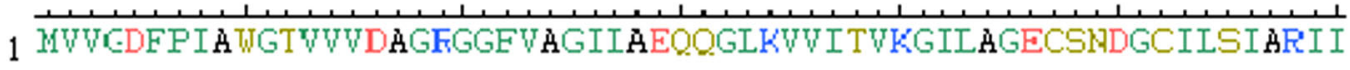

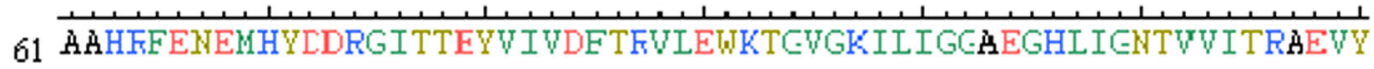

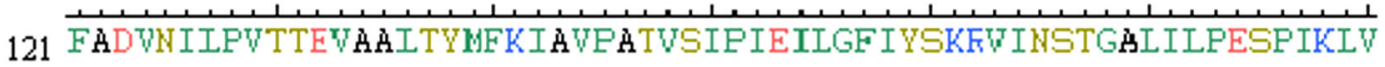

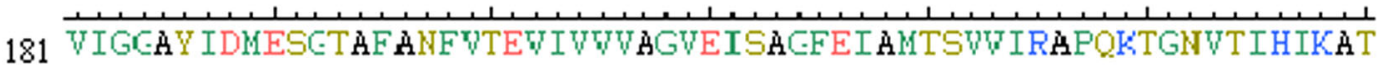

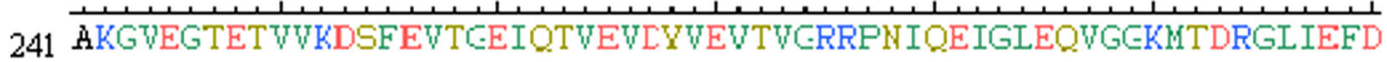

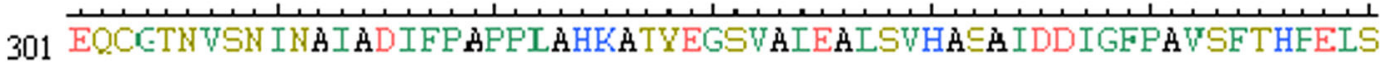

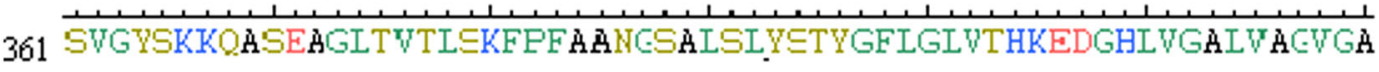

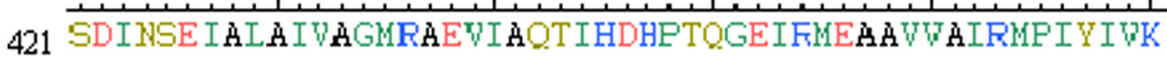

Fig. 4 Nucleotide (a) and protein (b) sequences of diaphorase from B. sphaericus. The numbers on the left and right are nucleotide accounts

amino acid sequence of $D L D$ gene had 68.30 and $54.89 \%$ similarity with $B$. anthracis and B. subtitlis, respectively. The restriction pattern of expression plasmid with BamHI and SalI confirmed gene cloning. An insert of $1413 \mathrm{bp}$ along with a $3.6-\mathrm{kb}$ vector band was observed after digestion (Fig. 3).

\section{Enzymatic characterization}

The native molecular mass of diaphorase enzyme was estimated to be about $50 \mathrm{kDa}$ by gel filtration chromatography. The subunit structure was examined by SDS-PAGE. SDS-PAGE gel analysis showed a single band indicating

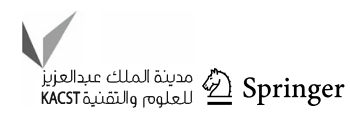




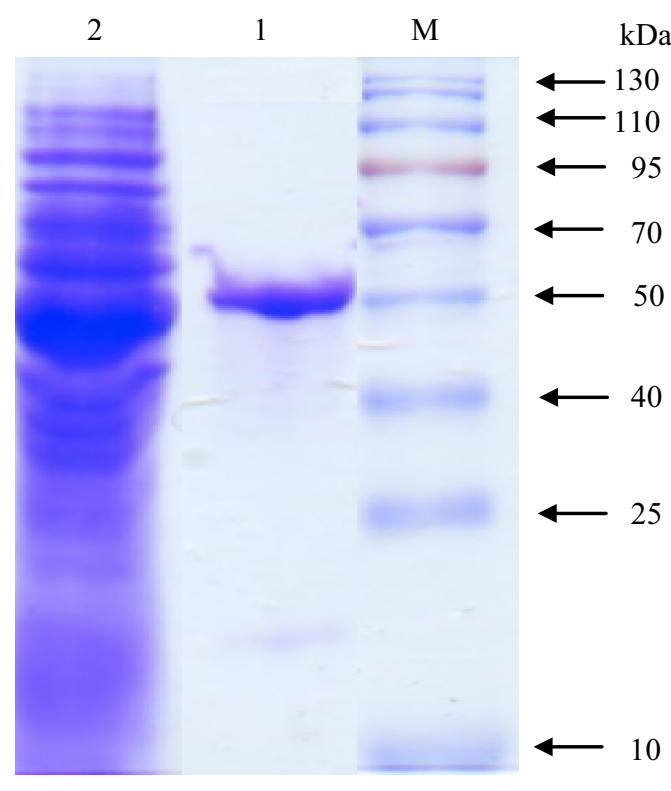

Fig. 5 SDS-PAGE analysis of the purified B. sphaericus recombinant enzyme. Lane $M$ protein molecular weight marker, lane 1 purified enzyme, lane 2 whole cell lysate
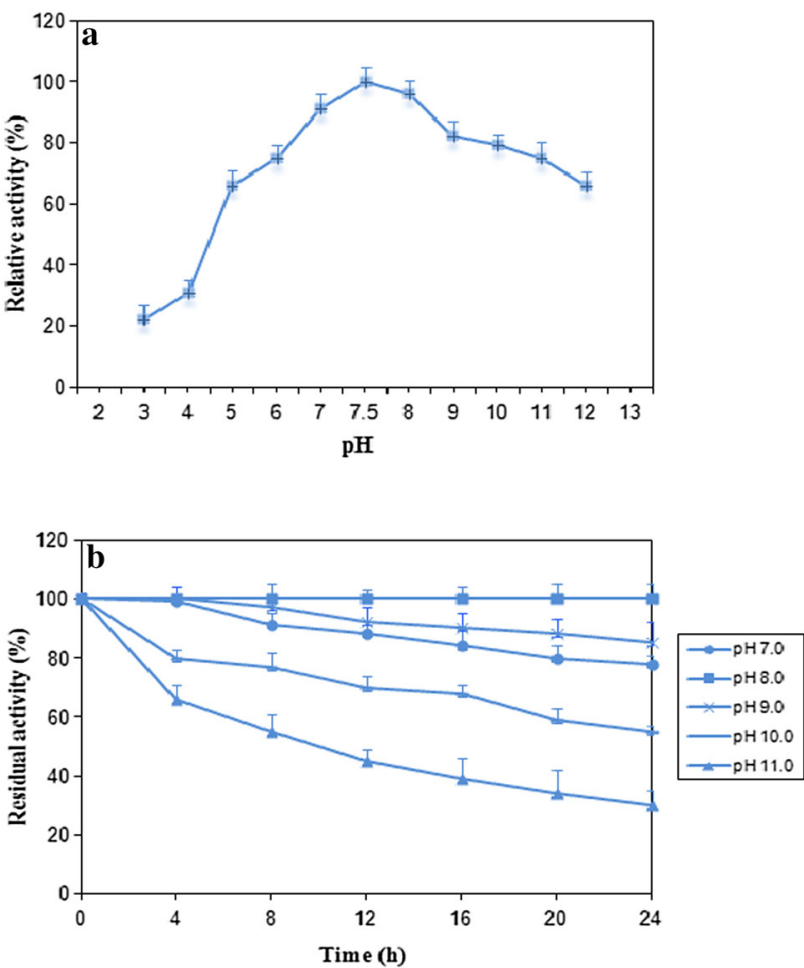

Fig. 6 Influence of $\mathrm{pH}$ on the activity (a) and stability (b) of diaphorase reaction. Each value represents mean $\pm \operatorname{SD}(n=3)$

that the enzyme was a monomeric protein (Fig. 5). This finding was in agreement with the previous reports in which many diaphorases have been shown to be monomers with MW values ranging from 50 to $55 \mathrm{kDa}$ (Kaplan et al.
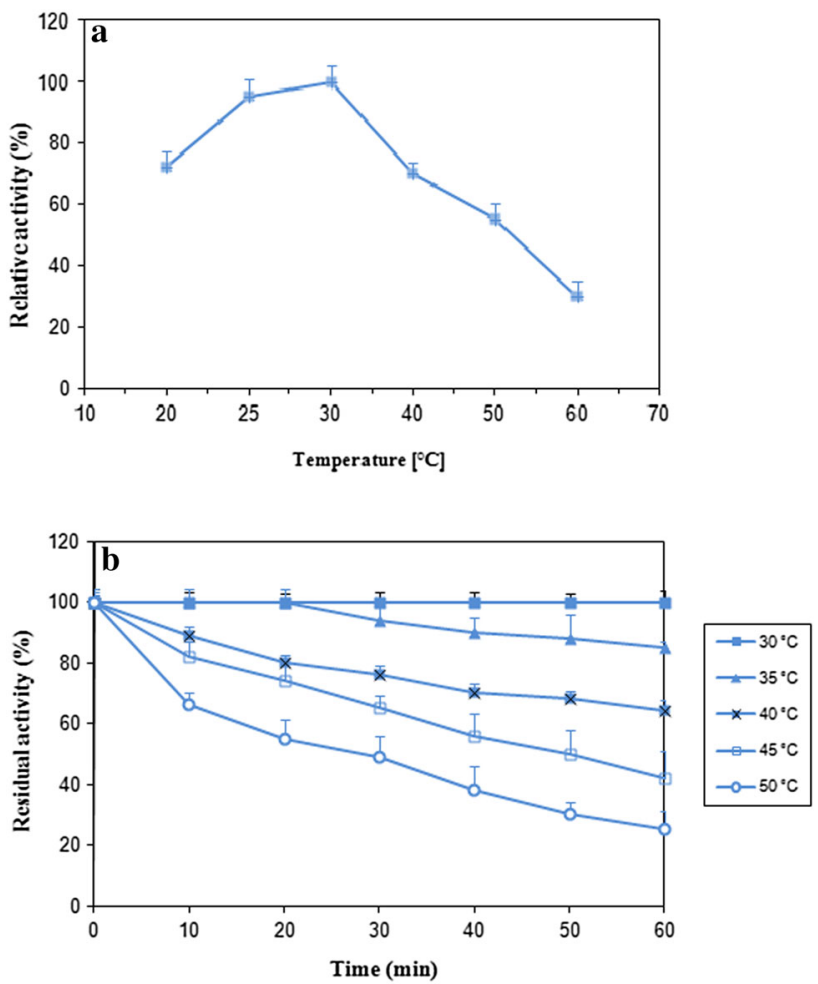

Fig. 7 a Influence of temperature and b time on the activity of diaphorase reaction. Each value represents mean $\pm \mathrm{SD}(n=3)$

1969). The effect of various $\mathrm{pH}$ values on the enzymatic reaction of diaphorase was evaluated in the $\mathrm{pH}$ range from 3.0 to 12.0 at $30{ }^{\circ} \mathrm{C}$. The optimum $\mathrm{pH}$ of the diaphorase reaction was approximately 8.5 and showed high activity in a pH range of 8.0-9.0 (Fig. 6a). The pH stability was also tested by measuring residual activity after incubation at different $\mathrm{pH}$ values for $24 \mathrm{~h}$. The enzyme was stable between $\mathrm{pH} 7.0$ and $\mathrm{pH}$ 9.0, while at $\mathrm{pH} 10$ it only retained $55 \%$ of its original activity during the same period incubation (Fig. 6b). The diaphorase reaction exhibited its maximal activity at $30{ }^{\circ} \mathrm{C}$ (Fig. 7a). As seen, a sharp decrease in enzyme activity was observed above $30{ }^{\circ} \mathrm{C}$ and was completely inactivated at $70{ }^{\circ} \mathrm{C}$. For examination of the temperature effect on enzyme stability, the residual activity of diaphorase incubated at different temperatures $\left(25-50{ }^{\circ} \mathrm{C}\right)$ for a period of $1 \mathrm{~h}$ was measured (Fig. $\left.7 \mathrm{~b}\right)$. The enzyme was almost stable at temperatures between 25 and $30{ }^{\circ} \mathrm{C}$ for $1 \mathrm{~h}$, but lost 15,36 and $58 \%$ of its initial activity after incubation for $1 \mathrm{~h}$ at 35,40 and $45^{\circ} \mathrm{C}$, respectively. At $50{ }^{\circ} \mathrm{C}$, target enzyme was completely inactivated after $50 \mathrm{~min}$. The $\mathrm{pH}$ and temperature profiles of B. sphaericus diaphorase correlated with reports of other diaphorases from C. kluyveri (Cakraborty et al. 2008) and B. subtitlis (Bhushan et al. 2002). The effect of metal ions and inhibitors was studied to determine which metal ions or inhibitors could enhance or reduce diaphorase activity. As seen 
Table 1 Effect of metal ions and inhibitors on the activity of $B$. sphaericus diaphorase

\begin{tabular}{ll}
\hline Reagents & Relative activity $(\%)$ \\
\hline None & 100.0 \\
$\mathrm{Zn}^{2+}$ & $98.5 \pm 3.7$ \\
$\mathrm{Cu}^{2+}$ & $99.3 \pm 1.5$ \\
$\mathrm{Mg}^{2+}$ & $97.6 \pm 1.8$ \\
$\mathrm{Ca}^{2+}$ & $99.2 \pm 2.1$ \\
$\mathrm{Fe}^{2+}$ & $98.4 \pm 3.2$ \\
$\mathrm{Mn}^{2+}$ & $97.1 \pm 2.7$ \\
$\mathrm{Co}^{2+}$ & $99.6 \pm 1.9$ \\
$\mathrm{Ba}^{2+}$ & $100.2 \pm 1.3$ \\
$\mathrm{Hg}^{2+}$ & $97.7 \pm 3.2$ \\
EDTA & $96.7 \pm 2.2$ \\
PMSF & $97.4 \pm 1.2$
\end{tabular}

The enzyme activity without any reagents was taken as $100 \%$. All metal ions and inhibitors were used at $5 \mathrm{mM}$. Data are given as mean $\pm \mathrm{SD}, n=3$

Table 2 Kinetic parameters of B. sphaericus diaphorase

\begin{tabular}{llllll}
\hline Substrate & $\begin{array}{l}\text { Specific } \\
\text { activity } \\
(\mathrm{U} / \mathrm{mg})\end{array}$ & $\begin{array}{l}K_{\mathrm{m}} \\
(\mathrm{mM})\end{array}$ & $\begin{array}{l}V_{\max }(\mathrm{U} / \\
\mathrm{ml})\end{array}$ & $\begin{array}{l}K_{\text {cat }} \\
\left(\mathrm{s}^{-1}\right)\end{array}$ & $\begin{array}{l}K_{\text {cat }} / K_{\mathrm{m}}\left(\mathrm{mM}^{-1}\right) \\
\left.\mathrm{s}^{-1}\right)\end{array}$ \\
\hline NADH & 250.72 & 0.33 & 200.0 & 108.9 & 330.0 \\
\hline
\end{tabular}

in Table 1, none of them enhanced or inhibited the enzyme activity. This was similar to the results achieved by other diaphorases (Dietrichs et al. 1990; Argyrou et al. 2003). Kinetic constants of the recombinant purified enzyme for
NADH substrate were determined. The results of kinetic parameters are depicted in Table 2. $K_{\mathrm{m}}$ and $V_{\max }$ values for $\mathrm{NADH}$ were estimated to be $0.33 \mathrm{mM}$ and $200.0 \mathrm{U} / \mathrm{ml}$, respectively (Fig. 8). The $K_{\mathrm{m}}$ value for NADH $(0.33 \mathrm{mM})$ was lower than the other previously reported diaphorases such as B. stearothermophilus $(0.7 \mathrm{mM})$ and $C$. kluyveri $(0.38 \mathrm{mM})$ (Cakraborty et al. 2008). The calculated $K_{\mathrm{m}}$ of the recombinant enzyme indicated high affinity for the NADH substrate. Moreover, the turnover number of the enzyme (108.9 $\left.\mathrm{s}^{-1}\right)$ was also higher than the other previously purified diaphorases. These kinetic features are very useful for the enzymological applications of B. sphaericus diaphorase.

\section{The potential of $B$. sphaericus diaphorase as a diagnostic tool}

Diaphorase enzymes are important analytical tools in clinical chemistry. They have the potential to be used as a component of in vitro diagnostic tests, e.g., diagnostic assays for PKU (Dilipkumar et al. 2013), MSUD and galactosemia (Shahbazmohammadi and Omidinia 2011). A diagnostic test in which the potential of desired enzyme was examined can be exemplified in the determination of galactose. As seen in Fig. 9, the regression equation for the two distinct reactions in the presence and without diaphorase enzyme was achieved as $Y=0.0126 x+0.0296$ and, $Y=0.0089 x+0.0331$, respectively. The correlation of coefficient $\left(R^{2}\right)$ for the reaction with diaphorase was 0.997 in comparison with without diaphorase (0.912). The short analysis time was another advantage of using
Fig. 8 Lineweaver-Burk plot for recombinant $B$. sphaericus diaphorase

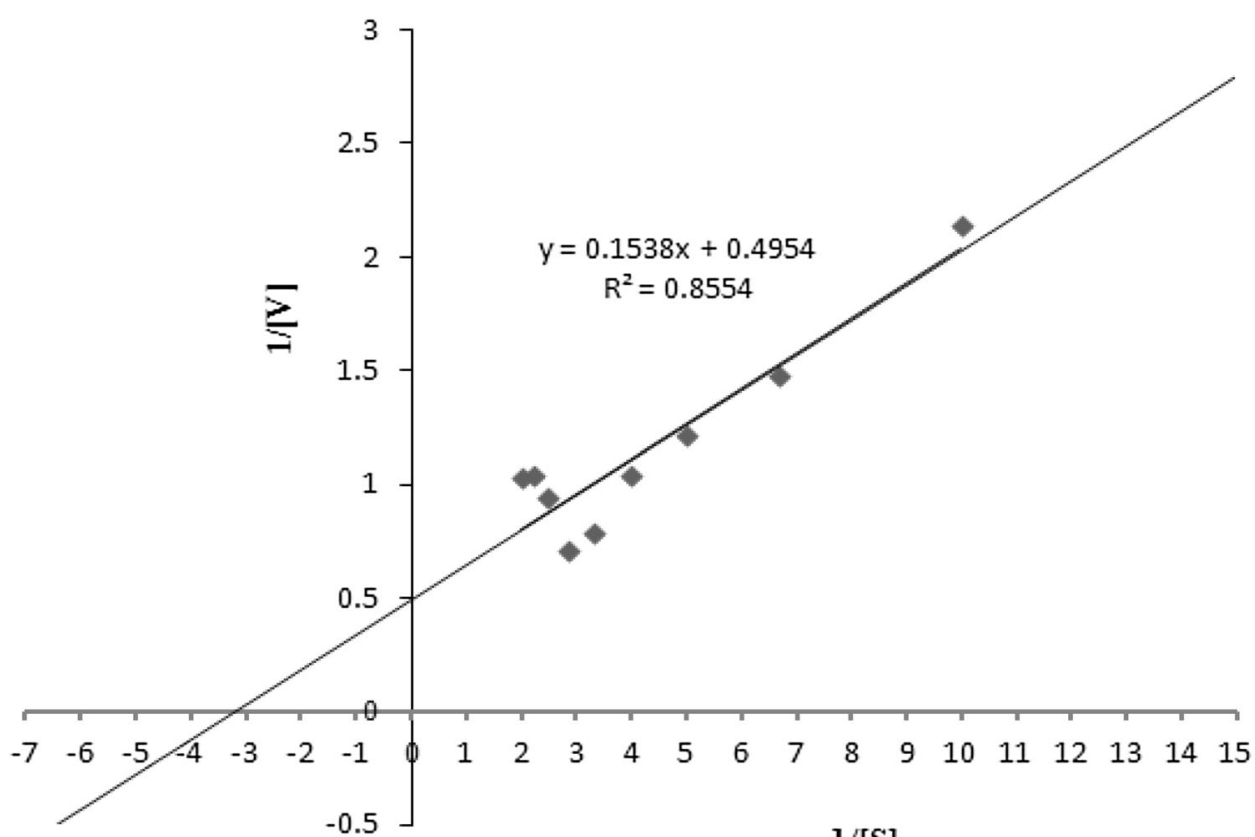

$1 /[\mathrm{S}]$ 


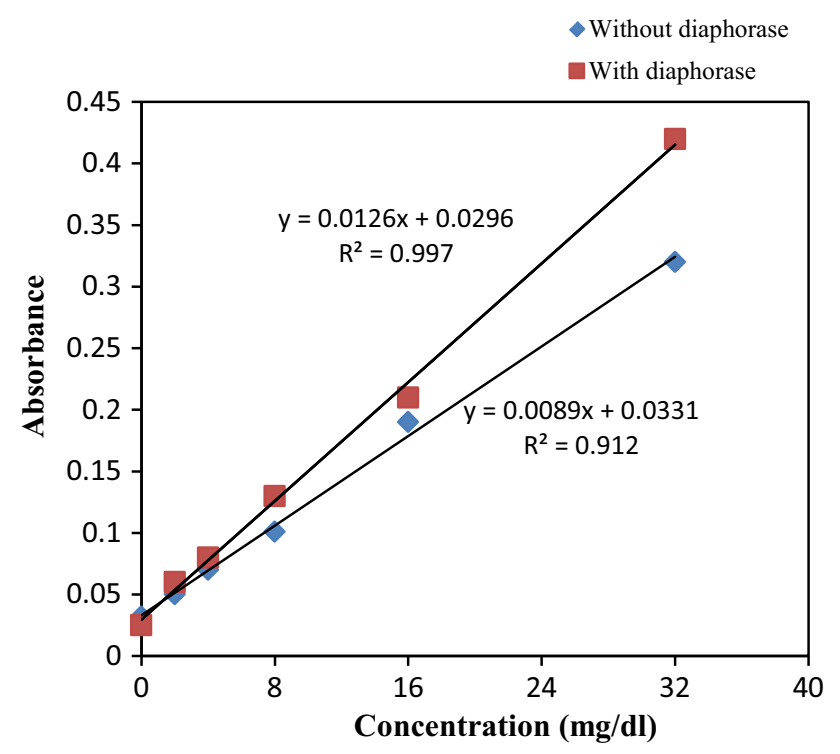

Fig. 9 Calibration curve for comparison of galactose concentration measurement with and without diaphorase. Experiments for each concentration were performed in triplicate run

diaphorase enzyme. Time required for assay in the presence diaphorase was 20 min which was favorably comparable than independent-diaphorase method (40 min). Resuming, the obtained results by diaphorase was that regression parameters of test was improved and assay time was decreased. These effects seemed to be related to the ability of target enzyme in electron transfer from NADH to electron acceptor (INT) as well as regeneration of NADH (Fig. 1) which leads to enhance of reaction velocity and better linearity (Gunther and Simon 1987). Similar results have also been found by $C$. kluyveri diaphorase (Cakraborty et al. 2008). Further examples where diaphorase can be applied in the measurement of metabolites are in the determination of phenylalanine and leucine (Kianmehr et al. 2016). Hence, given the above results, it can be concluded that $B$. sphaericus enzyme had potential to be a candidate for application in medicine as a diagnostic enzyme.

\section{Conclusion}

This paper presents recombinant expression, characterization and application of a DLD enzyme with diaphorase activity from a strain of $B$. sphaericus PAD-91. The $D L D$ gene consisted of $1413 \mathrm{bp}$ encoding a protein with MW of $50 \mathrm{kDa}$. Diaphorase exhibited its optimal activity at temperature of $30{ }^{\circ} \mathrm{C}$ and $\mathrm{pH}$ 8.5. The enzyme was compatible with different metal ions and inhibitors. $K_{\mathrm{m}}$ and $V_{\max }$ values of $B$. sphaericus enzyme with NADH were determined to be $0.33 \mathrm{mM}$ and $200.0 \mathrm{U} / \mathrm{ml}$, respectively. Collectively, the suitable kinetic features of B. sphaericus diaphorase can make this biocatalyst useful for application as a diagnostic enzyme.

Acknowledgements This Project has been financially supported by the office of vice chancellor for research and technology from the Islamic Azad University, Bandar Abbas Branch.

\section{Compliance with ethical standards}

Conflict of interest The authors declare that they have no conflict of interest.

Ethical statement This article does not contain any studies with human participants performed by any of the authors.

Statement on the welfare of animals All applicable international, national, and/or institutional guidelines for the care and use of animals were followed.

\section{References}

Adams MA, Jia Z (2006) Modulator of drug activity B from Escherichia coli: crystal structure of a prokaryotic homologue of DT-diaphorase. J Mol Biol 359:455-465

Antiochia R, Cass AEG, Palleschi G (1997) Purification and sensor applications of an oxygen insensitive thermophilic diaphorase. Anal Chem Acta 345:17-28

Argyrou A, Sun G, Palfey BA, Blanchard JS (2003) Calalysis of diaphorase reactions by Mycobacterium tuberculosis lipoamide dehydrogenase occurs at the EH4 level. Biochem 42:2218-2228

Benen JAE, Van Berkel WJH, Van Dongen WMAM, Muller F, Kok AD (1989) Molecular cloning and sequence determination of the Ipd gene encoding lipoamide dehydrogenase from Pseudomonas flurescens. J Gen Microb 135:1787-1797

Bhushan B, Halasz A, Spain JC, Hawari J (2002) Diaphorase catalyzed biotransformation of RDX via N-denitration mechanism. Biochem Biophys Res Commun 296:779-784

Boething RS, Weaver T (1979) A new assay for diaphorase activity in reagent formulations, based on the reduction of thiazolyl blue. Clin Chem 25(12):2040-2042

Cakraborty S, Sakka M, Kimura T, Sakka K (2008) Characterization of a dihydrolipoyl dehydrogenase having diaphorase activity of Clostridium kluyveri. Biosci Biotech Biochem 72(4):982-988

Dietrichs D, Meyer M, Schmidt B, Andreesen JR (1990) Purification of NADPH-dependent electron transferring flavoproteins and $\mathrm{N}$-terminal protein sequence data of the dihydrolipoamide dehydrogenase from anaerobic, glycine-utilizing bacteria. J Bacteriol 172:2088-2095

Dilipkumar M, Rajasimman M, Rajamohan N (2013) Enhanced inulinase production by Streptomyces sp. in solid state fermentation through statistical designs. 3 Biotech 3:509-515

Gunther H, Simon H (1987) The use of pig heart dihydrolipoamide dehydrogenase (diaphorase) for the regeneration of NADH or NAD. Appl Microbiol Biotechnol 26(1):9-12

Kaplan F, Setlow P, Kaplan NO (1969) Purification and properties of a DPNH-TPNH diaphorase from Clostridium kluverii. Arch Biochem Biophys 132:91-98

Ki J-S, Zhang W, Qian P-Y (2009) Discovery of marine Bacillus species by $16 \mathrm{~S}$ rRNA and rpoB comparisons and their usefulness for species identification. J Microbiol Methods 77:48-57

Kianmehr A, Mahrooz A, Ansari J, Oladnabi M, Shahbazmohammadi $\mathrm{H}$ (2016) The rapid and sensitive quantitative determination of 
galactose by combined enzymatic and colorimetric method: application in neonatal screening. Appl Biochem Biotechnol 179:283-293

Madiagan RA, Mayhew SG (1993) Preparation of the apoenzyme of the FMN-dependent Clostridium Kluyveri diaphorase by extraction with apofalvodoxin. Biochem Soci Transform 22:578-585

Mashayekhi Mazar F, Shahbazmohammadi H, Ebrahimi-Rad M, Gregorian A, Omidinia E (2012) Isolation, purification and characterization of a thermophilic alkaline protease from Bacillus subtilis BP-36. J Sci 23:7-13

Rlyachko NL, Shchedrina VA, Efimov AV, Kazakov SV, Gazaryna IG, Kristal BS, Brown AM (2006) pH-dependent substrate preference of pig heart lipoamide dehydrogenase varies with oligomeric state. J Biol Chem 280(16):16106-16114

Sambrook J, Fritsch EF, Maniatis T (1994) Molecular cloning: a laboratory manual, 2nd edn. Cold Spring Harbor Laboratory press, Cold Spring Harbor, pp 1847-1857

Serrano A (1992) Purification, characterization and function of dihydrolipoamide dehydrogenase from cyanobacterium $A n$ abaena sp. strain P.C.C.7119. Biochem 288:823-830

Shahbazmohammadi H, Omidinia E (2011) New enzymatic colorimetric method for the quantiative detemination of phenyalanine in dry-blood spots. J Sci 22:15-20

Shahbazmohammadi H, Omidinia E, Sahebghadam Lotfi A, Saghiri R (2007) Preliminary report of NAD+-dependent amino acid dehydrogenase producing bacteria isolated from soil. Iran Biomed J 11(2):131-135
Shahbazmohammadi H, Mostafavi SS, Soleimani S, Bozorgian S, Pooraskari M, Kianmehr A (2015) Response surface methodology to optimize partition and purification of two recombinant oxidoreductase enzymes, glucose dehydrogenase and D-galactose dehydrogenase in aqueous two-phase systems. Protein Expr Purif 108:41-47

Tamura K, Peterson D, Peterson N, Stecher G, Nei M, Kumar S (2011) MEGA5: molecular evolutionary genetics analysis using maximum likelihood, evolutionary distance, and maximum parsimony methods. Mol Biol Evol 28:2731-2739

Tedeschi G, Chen S, Massey V (1995) Active site studies of DTdiaphorase empolying artificial falvins. J Biol Chem 270:2512-2516

Vaubel RA, Rustin P, Isaya G (2011) Mutation in the dimer interface of dihydrolipoamide dehydrogenase promote site-specific oxidative damages in yeast and human cells. J Biol Chem 286(46):40232-40245

Xia L, Björnstedt M, Nordman T, Eriksson LC, Olsson JM (2001) Reduction of ubiquinone by lipoamide dehydrogenase. An antioxidant regenerating pathway. Eur $\mathrm{J}$ Biochem 268(5):1486-1490

Yan L-J, Thangthaeng N, Sumien N, Forster MJ (2013) Serum dihydrolipoamide dehydrogenase is a labile enzyme. J Biochem Pharmacol Res 1(1):30-42 